\title{
Chemical, morphological, and thermogravimetric of Terminalia catappa Linn
}

\author{
Orquídea Vasconcelos dos SANTOS ${ }^{1 *}$, Natasha Dantas LORENZO², Suzana Caetano da Silva LANNES ${ }^{2}$
}

\begin{abstract}
The objective of this study is to evaluate the chemical composition, morphology, and the thermogravimetric behavior of the pulp of Terminalia catappa, also known as tropical almond. The analytical results show, based mainly on its lipid content, that this fruit has a considerable energy value. Its fiber content contributes to enhance the functional properties of the fruit. Morphological characteristics show a spongy-like structure with dispersion of starch granules and high concentration of fiber bundles, confirming the results of the chemical composition analysis. The thermogravimetric behavior exhibited by this fruit pulp when submitted to progressive temperature increase under dynamic air atmosphere shows that this raw material has great potential for industrial use due to its high absorption rate of water soluble and/or lipid-based compounds, allowing its use as a dietary complement or supplement ingredient in food products.
\end{abstract}

Keywords: thermogravimetric; micrographs; fruits.

Practical Application: The possibility of using this raw material as a dietary enrichment was evidenced by its functional and technological properties. The spongy aspect of the post-extraction material shows its high water and oil absorption capacity, confirming its suitability for use in the food industry.

\section{Introduction}

Terminalia catappa Linn is a member of the Combretaceae family, which comprises approximately 600 species. However, the two most common genera are Combretum and Terminalia, each consisting of about 250 species and wide applicability in the traditional African, Asian, and Indian medicine (Fyhrquist et al., 2002; Saleem et al., 2002; Martini et al., 2004). Terminalia catappa is a drupe with a fleshy pulp. During maturation, it changes color from green to dark purplish-red; it has an oleaginous kernel coated with a thin film (Thomson \& Evans, 2006; Ivani et al., 2008; González-Mendoza et al., 2009).

Tropical almonds or Terminalia catappa Linn are edible fruits used in foods, especially for children and birds and other animals. Its kernels, which are also edible, are a source of proteins and lipids (Cavalcante et al., 1986; Matos et al., 1992; Ivani et al., 2008).

Traditionally, only the fallen leaves of Terminalia catappa Linn are boiled or brewed as a drink (tea). These leaves have been used in folk medicine as an antidiarrheal and antipyretic in India, Philippines, and Malaysia. In Taiwan, it has been used to prevent liver tumors and to treat hepatitis.

In terms of its technological use, separating the edible parts of this fruit increase its use in various products as a raw material in the enrichment and/or supplementation of existing formulations in the food industry. The use of appropriate technologies can promote the separation of this fruit's fractions and process them into flour, pulp, and oils.
These by-products can have technological applications such as in the preparation of baked goods (breads, cakes, pastries, biscuits, cookies, cereal or protein bars, and pasta in general). These applications have led to the deepening of studies to investigate their potential functional properties. Therefore, this fruit can arouse more interest of pharmaceutical, chemical, oleochemical, and other industries (Teixeira, 2010; Sousa et al., 2011; Santos et al., 2012, 2013).

Some studies on the biological properties of Terminalia catappa Linn, have been carried out in the area of human health, and its antioxidant (Lin et al., 2001; Ko et al., 2002; Chyau et al., 2002, 2006) anti-inflammatory (Fan et al., 2004), antitumoral (Chen et al., 2000; Liu et al., 1996), antiviral (Tanaka et al., 1986), and antidiabetic (Nagappa et al., 2003) potential have been described.

Its macronutrients, such as carbohydrates, proteins, and lipids, can help the body in the daily diet by supplying energy and basic substances for the growth and maintenance of body functions; lipids and proteins are the most significant macronutrients present in Terminalia catappa kernel and pulp of (Lima, 2012).

Its micronutrients, on the other hand, help regulate human functions (Roach, 2009) and can be classified as: electrolytes (potassium, chloride, and sodium), macro minerals (calcium, phosphorus, magnesium, and sulfur) trace minerals or trace elements (iron, zinc, copper, iodine, chromium, selenium, manganese, molybdenum, and nickel) and ultratrace elements (fluorine, cobalt, silicon, vanadium, 
tin, lead, mercury, boron, lithium, strontium, cadmium, and arsenic) (Manganaro, 2008). The ultratrace and trace elements are essential for the proper body function and are required in small amounts (Roach, 2009).

The presence of phenolic compounds - aromatic compounds resulting from the secondary metabolism of plants - was also identified (Kim et al., 2003). These compounds have an adaptive protective role in the defense mechanism, and their importance has been demonstrated in several studies, particularly flavonols, anthocyanins, and antoxantins, confirming their ability to capture free radicals thus preventing cardiovascular and circulatory diseases, cancer, diabetes, and Alzheimer's (Wang \& Mazza, 2002; Stoclet et al., 2004; Abdille et al., 2005; Khatoon et al., 2008).

According to Nagappa et al. (2003), the presence of phenolic compounds indicates that the fruit has the potential to prevent and possibly treat certain diseases. Accordingly, the extracts from tropical almond (Terminallia C. Linn) have been described as hypoglycemic agents capable of regenerating pancreatic $\beta$-cells due to the presence of methanol and aqueous extracts.

Therefore, this study aims to evaluate the nutritional and colorimetric composition, morphology and thermogravimetric of tropical almond in order to obtain practical knowledge to add value to this fruit.

\section{Materials and methods}

\subsection{Fruit harvest}

The tropical almond (Terminalia catappa Linn) fruits used in this study (2014 fruit season), about $5.0 \mathrm{~kg}$, were collected from adult trees in the city of Belém - PA. This fruit was registered in the João Pires Murça (MG) Herbarium, also known as "herbárium Amazanicum Musei paraenses" under the code \# MG70506. The fruits were selected according to the maturity stage in which they are ready for consumption (dark purplish-red). The fruits were picked directly from the trees according to their external appearance.

\subsection{Sample preparation}

The fruit samples were transported in low density polyethylene (LDPE) bags to the Laboratory Food Analysis, Federal University of Pará, where they were rinsed with tap water, submerged in a sanitizing solution of $150 \mathrm{ppm}$ available chlorine for 5 minutes, drained, manually pulped separating the pulp from the kernels, and stored at $7{ }^{\circ} \mathrm{C}$.

\subsection{Microbiological analysis}

The tropical almond samples were submitted to microbiological analysis to detect the presence coliforms at $45^{\circ} \mathrm{C}$ and Salmonella sp., pursuant to Resolution-RDC 12 of January 2, 2001 (Brasil, 2001), and to determine the count of aerobic mesophilic bacteria (plate count method), according to the methods described by Silva et al. (2001).

\subsection{Biometric analysis}

The fruits were randomly selected and the cutting point was chosen considering the presence of mechanical injury or uniformities that prevented the accurate measurements of their diameters. Subsequently, they were weighed using an analytical balance (QUIMIS- Bioprecisa electronic balance FA-2104N), and the largest and smallest diameters were measured using a caliper (VONDER).

\subsection{Physicochemical characterization of tropical almonds}

Physicochemical properties of pulp and peel

- Water activity: obtained by direct measurement using an AquaLab thermo hygrometer Series 3TE (DECAGON) with internal temperature control of $25^{\circ} \mathrm{C}$;

- $\mathrm{pH}$ : measured according to the AOAC official method 981.12 (Association of Official Analytical Chemists, 2000) using a potentiometer (QUIMIS) previously calibrated with buffer solutions of $\mathrm{pH} 4$ and 7;

- Soluble solids: determined by refractometry according to the IAL method (Instituto Adolfo Lutz, 1985) using an AR200 manual digital refractometer (Tecnal).

- Total Acidity: determined according to the AOAC official method 22.058 (Association of Official Analytical Chemists, 2000) that measures the acidity of substances.

- Humidity: determined according to the AOAC official method 920151 (Association of Official Analytical Chemists, 2000) by drying in a forced-air oven at $105^{\circ} \mathrm{C}$ until constant weight;

- Crude protein: determined according to the micro-Kjeldahl as described by the AOAC official method 950.48 (Association of Official Analytical Chemists, 2000), which is based on determining the total amount of nitrogen existing in the sample; crude protein content is calculated by multiplying the total nitrogen by $6.25(\% \mathrm{~N} \times 6.25)$;

- Total lipids: determined by solvent extraction on a Soxhlet apparatus according to the AOAC official method 948.22 (Association of Official Analytical Chemists, 2000) using petroleum ether as solvent;

- Fixed mineral residue: ash content was determined by incinerating the sample in a muffle furnace at $550{ }^{\circ} \mathrm{C}$, according to the AOAC official method 930.05 (Association of Official Analytical Chemists, 2000);

- Crude fiber: determined using the acid detergent (ADF), according to the method developed by Van Soest (1967);

- Total Carbohydrates: determined by difference (100-total moisture + protein + fat + fiber + ash in $100 \mathrm{~g}$ of food), according to the RDC Resolution No. 360, December 23, 2003 (Brasil, 2003);

- Energy value: was calculated using the Atwater conversion factors $4-9-4 \mathrm{kcal} / \mathrm{g}$ for protein, fat, and total carbohydrate, respectively, according to the Resolution-RDC 360 of December $23^{\text {th }}, 2003$ (Brasil, 2003). 


\section{Colorimetric analysis}

Color analysis of in natura pulp was conducted using a CE Minolta CR-310 colorimeter. All color data were expressed by $L^{\star}, a^{*}$, and $b^{\star}$ values, where $L^{*}$ corresponds to lightness; $a^{*}$ corresponds to the transition from green $\left(-a^{\star}\right)$ to red $\left(+a^{\star}\right)$; and $\mathrm{b}^{\star}$ corresponds to the transition from blue $\left(-\mathrm{b}^{*}\right)$ to yellow $\left(+\mathrm{b}^{*}\right)$. The measurements were carried out in triplicate.

The international standards and the nomenclature for the measurement of color used by the food industry were defined by the Commission Internationale de l'éclairage (CIE) in 1931. In the present study, the CIELAB system $\left(\mathrm{L}^{*}, \mathrm{a}^{*}, \mathrm{~b}^{*}\right)$ reported by Motta (2005) was used. The equipment was set up using the following parameters defined by the manufacturer: $L^{*}=97.51$, $\mathrm{a}^{*}=+0.34$, and $\mathrm{b}^{*}=+1.73$. Color change was calculated as the difference between the fruit samples with different maturity stages, and it expresses color variation $(\Delta \mathrm{E})$, according to Equation 1; the results also express Chroma, and hue angle values, Equations 2 and 3, respectively.

$$
\begin{aligned}
& \Delta E=\left[\left(\Delta L^{*}\right)^{2}+\left(\Delta a^{*}\right)^{2}+\left(\Delta b^{*}\right)^{2}\right]^{1 / 2} \\
& C^{*}=\sqrt{\left(a^{2}\right)+\left(b^{2}\right)} \\
& H^{*}=\operatorname{arctang}\left(\frac{b^{*}}{a^{*}}\right)
\end{aligned}
$$

\section{Scanning Electron Microscopy (SEM)}

The morphological analyses of the defatted flour of Terminalia catappa were conducted by Scanning Electron Microscopy (SEM) in samples previously dried in a muffle furnace with integrated air circulation at $105^{\circ} \mathrm{C}$ for 24 hours. Subsequently, the samples were placed on $20 \mathrm{~nm}$ thick metal trays (Silveira, 1989). The Scanning electron micrographs were performed using a TM 3000 tabletop microscope (HITACHI).

\section{Thermogravimetric characterization}

- Thermogravimetric and Differential Thermal Analyzes (TG-DTA): were performed on Shimadzu thermobalances (DTG $60 \mathrm{H}$ ) in air atmosphere and air flow of $50 \mathrm{~mL} / \mathrm{min}$, heating ramp rate of $10{ }^{\circ} \mathrm{C}$, and temperature at $400{ }^{\circ} \mathrm{C}$ using aluminum crucibles and mass $5 \pm 0.5 \mathrm{mg}$.

\subsection{Statistical analysis}

The physicochemical analyses were performed in triplicate (mean \pm standard deviation), and the colorimetric results were statistically analyzed using the Statistica ${ }^{\circledR}$ software, version 7.0 (Statsoft Inc., 1995) and the following statistical methods:

- Analysis of variance (ANOVA) at the 5\% significance level, according to the F test;

- Tukey test $(\mathrm{p} \leq 0.05)$.

\section{Results and discussion}

\subsection{Biometric analysis}

The data of the measurements of the physical properties of the tropical almond fruits (Terminalia catappa Linn.) are discussed below. The average weight of the kernel, pulp, and peel were $9.71 \pm 2.46 \mathrm{~g}, 4.22 \pm 2.23 \pm 6.01 \mathrm{~g}$, and $3.28 \mathrm{~g}$, respectively. Marques et al. (2011), investigating 20 tropical almonds, found the following average weights: $19.60 \mathrm{~g} \pm 0.00$ in whole fruits, $11.24 \pm 2.35 \mathrm{~g}$ in the pulp, and $1.08 \pm 0.00 \mathrm{~g}$ in the peel. On the other hand, Cavalcante et al. (1986) found $13.72 \pm 0.00 \mathrm{~g}$ in pulp, and $2.32 \pm 0.00 \mathrm{~g}$ in the peel investigating a total of 86 fruits. According to Souto et al. (2008), this variability of results can be explained by the age of the tree, growing conditions, climate, and use of fertilizers among others.

The biometric measurements of length $(\mathrm{cm})$ and width $(\mathrm{cm})$ in the whole fruit were: $4.49 \pm 0.52$ and $3.50 \pm 0.47$, respectively; in the kernel $(\mathrm{g})$, it was $9.84 \pm 2.44$. Ivani et al. (2008) and Lima (2012), found close values, $5.51 \pm 0.48 \mathrm{~cm} .3 .99 \pm 0.44 \mathrm{~cm}$, $5.00 \pm 0.48 \mathrm{~cm}$, and $3.82 \pm 0.42 \mathrm{~cm}$, respectively, in the whole fruit.

The yield of edible portion of the tropical almond fruit was $49.97 \%$ for the pulp and peel and $47.58 \%$ for the kernels. Cavalcante et al. (1986) found a yield of around $35.80 \%$ for the pulp, while Marques et al. (2011), obtained higher values (57.34\%). An average weight of $20.67 \mathrm{~g}$ shows that if we consume five units of this fruit per day, $13.40 \%$ of our total daily energy requirements will be fulfilled.

\subsection{Microbiological analysis}

The results of the tropical almond microbiological analysis are shown according to the standards established by law, and they demonstrate that this fruit is fit for human consumption since Salmonella sp. $25 \mathrm{~g}$ was not detected. The presence of coliforms at $45{ }^{\circ} \mathrm{C}$ was detected at levels far below the permissible legal levels (maximum value of $10^{2} / \mathrm{g}$ (Brasil, 2001).

However, since this fruit has a high water activity, analysis of mesophilic bacteria was conducted by standard plate counting method. Despite its high water activity, the results showed $2.7 \times 10^{4} \mathrm{CFU} / \mathrm{g}$, indicating that this value meets the regulatory requirements; according to the law, food with values higher than $10^{6} \mathrm{CFU} / \mathrm{g}$ are unfit for human consumption (Brasil, 2001).

\subsection{Physicochemical characteristics}

\section{Physical and physicochemical characterization}

The high levels of water activity obtained can lead to the growth and proliferation of microorganisms such as bacteria; the growth of most microorganisms is confined to the AW range above 0.90 .

Lima (2012) found $\mathrm{pH}$ value of $4.85 \pm 0.05$, which are higher than that found in the present study $(4.15 \pm 0.25)$, showing that this fruit is a good alternative for the industrial production of beverages since low $\mathrm{pH}$ levels do not require the acidification step in the manufacturing process. 
Total soluble solids (Degrees Brix) along with other parameters can be associated to fruit maturity stage. There are no studies on the postharvest of tropical almonds available in the literature, which can probably explain the differences in the values obtained in different studies, such as in the studies conducted by Lima (2012) and Marques et al. (2011), who found total soluble solids values ( ${ }^{\circ} \mathrm{Brix}$ ) of $9.86 \pm 1.56$ and $8 \pm 0.00$, respectively; Paula (2008), who obtained a higher mean value (12.96 \pm 0.52$)$; and Arrázola et al. (2008), who found $10.86 \pm 0.00^{\circ} \mathrm{Brix}$, a value similar to those obtained here $(11.8 \pm 0.2)$, corroborating the results found in the present study.

The level of soluble solids (Brix) in fruits is of great importance since the higher the soluble solid content, the lower the amount of sugar added to the fruit in the industrial processing, which can reduce production cost, water evaporation, and energy consumption, resulting in a higher product yield and lower processing costs (Silva \& Queiroz, 2002; Costa et al., 2004).

Another important parameter assessed was total acidity (g citric acid/100 g) of the pulp, with a value of $0.11 \pm 0.001$, which is similar to the value obtained by Arrázola et al. (2008), $0.12 \%$, in the ripe pulp of this fruit. Lima (2012), on the other hand, found a value of $0.38 \% \pm 0.02$. High total acidity in the pulp can be responsible for sharp or sour taste of the pulp, which can lead to high dilution factor in the production of juices, increasing industrial productivity.

\section{Proximate composition}

The results of proximate analysis of the tropical almonds obtained in the present study and those found by other authors are shown in Table 1.

The results in Table 1 show that tropical almond had high humidity, which affects its conservation; this parameter was also associated with water activity.

The ash content of Terminalia catappa obtained was higher than those in the other studies listed in Table 1; therefore, it can be said it is a rich source of minerals and that it has several functions in the body, both in its ionic form in body fluids and as constituents of essential compounds.

As for the protein content, it was observed that the tropical almond peel and pulp had values higher than those found by Lima (2012) and Marques et al. (2011). This shows that this fruit may possibly have essential and nonessential amino acids enough to correct protein deficiency in children suffering from malnutrition in developing countries, as shown by Oliveira et al. (2000).

Therefore, Terminalia catappa proteins can be used in the formulation of protein bars contingent upon its physicochemical characteristics such as: shape; amino acid composition; net charge and charge distribution hydrophilic/hydrophobic ratio; primary, secondary, tertiary, and quaternary structures; flexibility-stiffness; and ability to react with other components, which affect the food behavior during processing, storage, and preparation, determining the quality attributes of the final product.

Lipid values were higher than those obtained by Lima (2012) and Marques et al. (2011), showing that its fatty material may contain significant levels of oleic acid and other essential fatty acids such as linolenic acid, as reported by Ajayi et al. (2008).

Terminalia catappa is solid at room temperature, and therefore it is a fat not an oil; its structures are more stable due to the fact that they are arranged in high adhesivity layers, and thus its hydrocarbon chains have a linear shape (Lehninger et al., 2002; Fennema, 2010). It is likely that its environmental condition resistance is high, which means good thermal stability; therefore, it can be used as a vegetable shortening.

The total fiber content found $(31.68 \pm 0.4)$ was higher than those of the other two studies. According to the ordinance $n^{\circ} 27$, January $13^{\text {th }} 1998$ (Brasil, 1998), foods containing at least 6 grams of dietary fiber per 100 grams of solid product are considered foods high in nitrogen. Therefore, Terminalia catappa can be considered as a food rich in fibers.

The presence of dietary fibers in foods is of great interest to health since epidemiological studies have reported an inverse correlation between fiber intake and some types of cancer, cardiovascular disease, diverticulitis, appendicitis, gallstones, varicose veins, diabetes, and hemorrhoid. An increased fiber intake increase fecal softness, fecal bulk, water holding capacity, organic biding capacity, and reduce the intestinal transit time, enhancing the removal of stagnant potentially detrimental materials from the bowels (Devries, 2009).

Carbohydrate concentration was higher than that found by Lima (2012) and lower than that obtained by Marques et al. (2011); this result can be explained by the corresponding amount

Table 1. Proximate composition values of tropical almond obtained in different studies.

\begin{tabular}{lcrr}
\hline \multicolumn{1}{c}{ Parameters } & Values obtained & $\begin{array}{c}\text { Values obtained by } \\
\text { Marques et al. (2011) }\end{array}$ & $\begin{array}{c}\text { Values obtained by } \\
\text { Lima (2012) }\end{array}$ \\
\hline Humidity (\%) & $16.54 \pm 0.50$ & $17.20 \pm 1.13$ & $83.25 \pm 0.25$ \\
Ashes (\%) & $4.11 \pm 0,38$ & $0.83 \pm 0,24$ & $0.73 \pm 0.04$ \\
Proteins (\%) & $2.54 \pm 0.40$ & $2.30 \pm 0.00$ & $1.04 \pm 0.18$ \\
Lipids (\%) & $14.95 \pm 0.64$ & $2.79 \pm 0.58$ & $0.16 \pm 0.03$ \\
Carbohydrate (\%) & $11.27 \pm 0.20$ & $76.88 \pm 0.58$ & $6.87 \pm 0.06$ \\
Starch & $19.57 \pm 0.25$ & $*$ & $*$ \\
Total fibers (\%) & $31.68 \pm 0.40$ & $*$ & $7.95 \pm 0.05$ \\
TEV (Kcal.100 $\mathrm{g}^{-1}$ ) & 268.07 & 341.83 & 33.08 \\
\hline
\end{tabular}

*Values not shown. 
Table 2. Colorimetric analysis of tropical almonds in different maturity stages.

\begin{tabular}{|c|c|c|c|c|c|}
\hline \multirow{2}{*}{ Sample } & \multicolumn{3}{|c|}{ Color Coordinates } & \multirow{2}{*}{$\begin{array}{c}\text { Hue } \\
\text { Hue }^{* *} \\
\end{array}$} & \multirow{2}{*}{$\begin{array}{c}\text { Saturation } \\
\text { Chroma }\end{array}$} \\
\hline & $\mathrm{L}^{*}$ & $a^{*}$ & $\mathrm{~b}^{*}$ & & \\
\hline Ripe & $48.16 \pm 0.04^{\mathrm{b}}$ & $8.78 \pm 0.02^{c}$ & $10.79 \pm 0.03^{\mathrm{a}}$ & $50.88 \pm 0.11^{\mathrm{a}}$ & $13.91 \pm 0.03^{\mathrm{a}}$ \\
\hline Yellowish & $52.01 \pm 0.18^{c}$ & $0.72 \pm 0.07^{\mathrm{b}}$ & $18.24 \pm 0.11^{\mathrm{c}}$ & $87.74 \pm 0.23^{\mathrm{b}}$ & $18.25 \pm 0.11^{\mathrm{b}}$ \\
\hline
\end{tabular}

${ }_{\mathrm{a}, \mathrm{b}, \mathrm{c}}$ In a column, means with different superscripts significantly differ at $\mathrm{P}<0.05 .{ }^{* *}$ Degrees.

of total sugars, $33.33 \% \pm 0.00$, and the presence of reducing sugars, $27.32 \% \pm 0.42$, non-reducing sugars, $6.01 \%$, and sucrose, $5.71 \%$.

The total energy value (TEV) was higher than that obtained by Lima (2012) and lower than that reported by Marques et al. (2011), showing that the daily intake consumption of $100 \mathrm{~g}$ of tropical almonds (approximately five fruits) can supply $13.40 \%$ of the calorie needs of adults based on a $2000 \mathrm{kcal}$ calorie diet.

The discrepancy between the results may be due to the fact that the fruits were collected from different places in the three studies compared, showing the influence of the climate and soil of each region (Souto et al., 2008).

\subsection{Colorimetric analysis}

Food color is the first characteristic observed by consumers, and it predetermines perceptions of taste and quality (Henry, 1996). The three color quality dimensions are hue $\left(h^{*}\right)$, saturation $\left(\mathrm{C}^{\star}\right)$, and lightness $\left(\mathrm{L}^{\star}\right)$. Saturation, also called purity, describes the intensity or saturation level of a particular hue indicating the degree to which the color differs from black, white, and gray; it is the quality by which we distinguish a strong color from a weak one.

Lightness defines the perceived intensity of the color indicating whether the colors are bright or dark $\left(\mathrm{L}^{*}=0\right.$, black and $\mathrm{L}=100$ white). Delta values $\left(\Delta \mathrm{L}^{*}, \Delta \mathrm{a}^{*}\right.$, and $\left.\Delta \mathrm{b}^{*}\right)$ indicate how the sample differed in $\mathrm{a} \mathrm{L}^{\star}, \mathrm{a}^{\star}$ and $\mathrm{b}^{\star}$ color space, and are often used for quality control and formula adjustments and to calculate the total color difference $\left(\Delta \mathrm{E}^{\star}\right)$ (Hunterlab, 1996; Pontes, 2004; Ramos \& Gomide, 2007).

Tables 2 and 3 show the results (mean \pm standard deviation) of colorimetric analysis of tropical almonds in different maturity stages: ripe, yellow, and unripe, and their respective variance analysis (ANOVA) results at $5 \%$ of significance level and Tukey test at $\mathrm{p} \leq 0.05$.

As for the values of the coordinate $\mathrm{a}^{*}$, the value of the ripe samples $(8.78 \pm 0.02)$ indicated tendency to red color, and the $\mathrm{b}^{\star}$ value indicated tendency to yellow. The yellow samples had an $a^{*}$ value close to 0 , and the $b^{*}$ value indicated tendency to yellow color. The values of $\mathrm{a}^{*}$ and $\mathrm{b}^{*}$ of the unripe samples did not show tendency to yellow or green colors, respectively.

The ripe samples showed orange hue $\left(h^{*}\right)$. On the other hand, the yellowish samples had a $h^{\star}$ value close to yellow, and the unripe samples showed green hue. The Chroma values of all samples showed tendency to black color, i.e. all fruits were dark colored. The statistical analysis of the data did not show significant difference between ripe and unripe fruits at the
Table 3. Difference in the color of the fruit samples according to their maturity stage.

\begin{tabular}{cc}
\hline Color change in the samples & Total color change $(\Delta \mathrm{e})$ \\
\hline Green & 12.01 \\
Yellow & 11.63 \\
Dark purplish-red & 16.63 \\
\hline
\end{tabular}

level of significance of $5 \%$, unlike the other data that differed significantly at this significance level.

Comparing the data in Table 3 , it can be seen that the $L^{*}$ (lightness) value of the yellow samples demonstrates a balance between the tendency towards a darker or lighter color; the same behavior was observed for the green samples. The total color change $\left(\Delta \mathrm{e}^{\star}\right)$ values of this fruit showed statistically significant difference only between the dark purplish-red samples.

\subsection{Morphological analysis of the defatted flour of terminalia catappa}

Figures 1,2, and 3 show the micrographs of the defatted flour of tropical almonds.

The study of the microscopic structures of the terminalia catappa defatted flour contributes to deepen and corroborate the available knowledge about the composition and characterization of the morphological structures of this raw material, focusing on the determining parameters for the identification of its microscopic structure in foods prepared with this fruit.

The micrographs in Figures 1 and 2 show an overview of irregular arrangements of non-uniform porous structure with starch granules unevenly distributed throughout the structure. These granules are oval or rounded-shaped and their surfaces are not uniformly smooth, which probably results from the strong interaction between them and the fibrous matrix. Sample preparation exerts a certain pressure on the starch granules causing small structural deformations after the drying process and the lipid extraction steps.

The microscopy of Figure 3 confirms the high fiber content found in the physicochemical analysis, as shown in Table 1.

The structure of this raw material regarding the presence of longitudinal bundles of fibrous material can also show the potential of this fruit to be used in the fortification of other flours and/or to it's in natura consumption in a regular diet, justifying its role in the regulation of intestinal transit.

Yonemoto et al. (2007), Santos (2008), Santos et al., (2013) have concentrated special attention to the morphological 


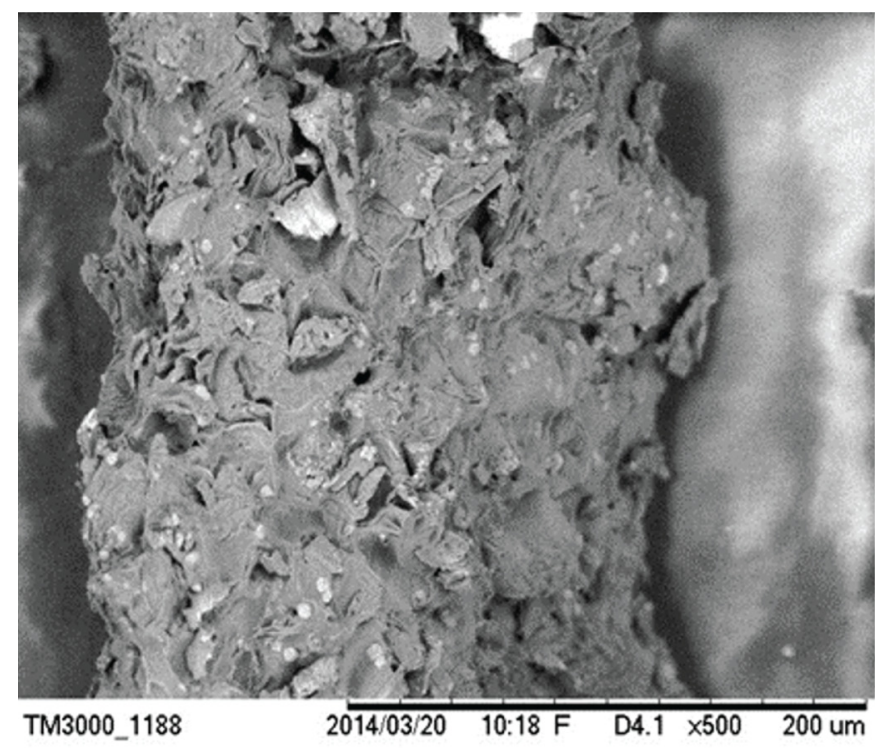

Figure 1. Structural overview.

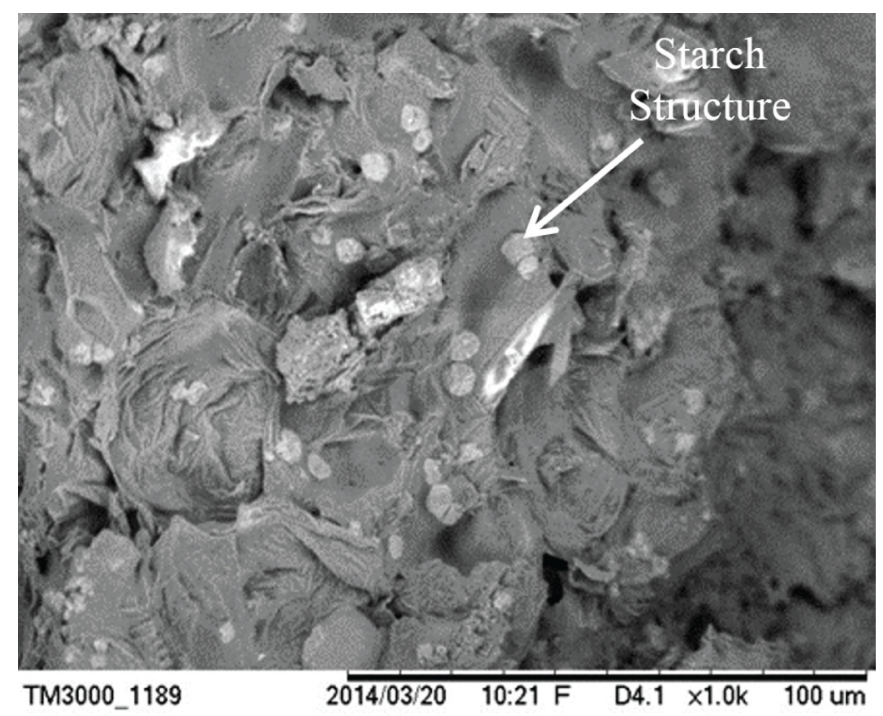

Figure 2. Starch granules.

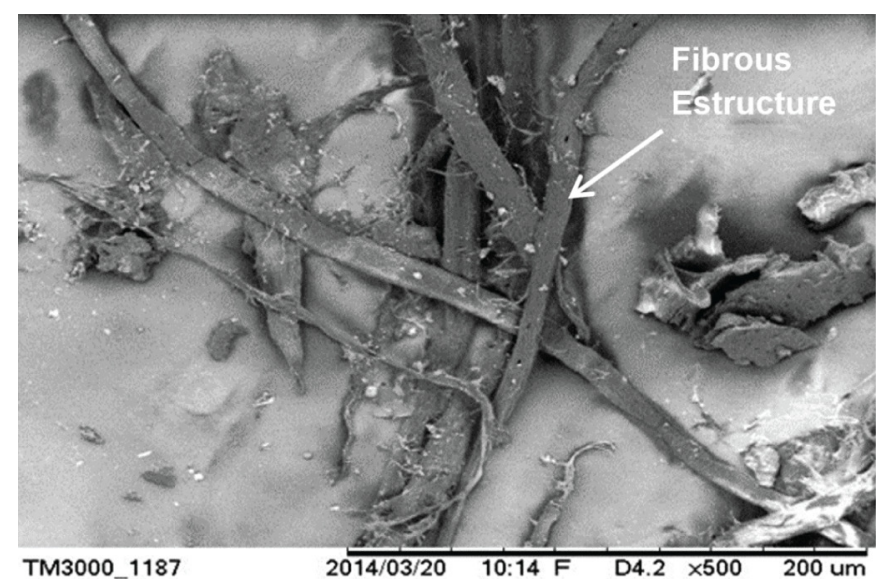

Figure 3. Fiber bundles.

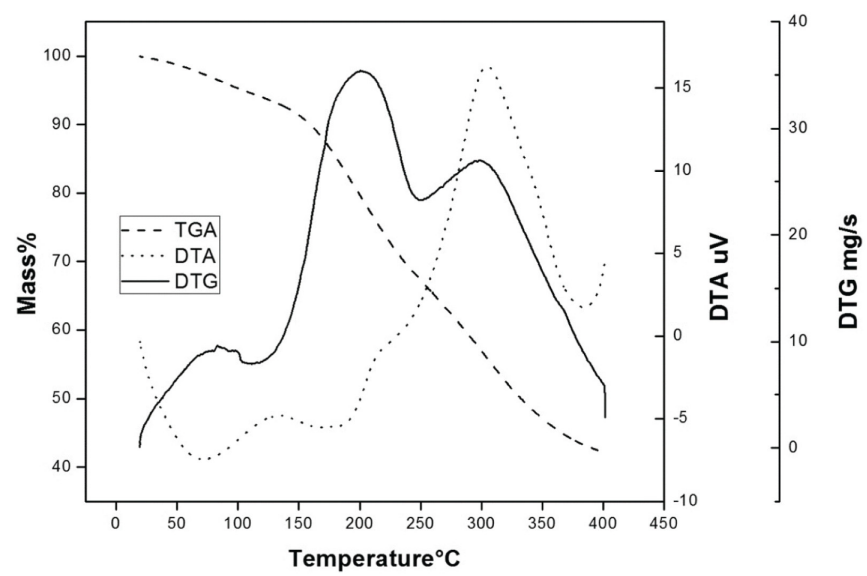

Figure 4. TG/DTA curves of tropical almond defatted flour.

characteristics of starches and proteins. These authors found two types of granules: the largest had a lenticular shape and the smallest had round or polygonal shapes.

The characteristics of the tropical almond starch granules are similar to those found by Gonçalves et al. (2009) in starch granules of sweet potato, which were round and oval shaped structure. This indicates that their potential for food application is similar to that of sweet potatoes due to its probable capacity to absorb water and oil resulting from its porous structure, making this material another alternative combination of compound and matrix for various sectors of the food industry.

\subsection{Thermogravimetric and differential thermal analysis (TG/DTA)}

The graphic behavior of the thermogravimetric and differential curves of the defatted material is shown in Figure 4.

The by-product obtained from the extraction of the fatty material of this raw material (Figure 4) exhibited thermogravimetric behavior, as shown by the TG/DTA curves. The results showed a tendency to decrease due to the weight loss initially caused by the water loss in the material at $100{ }^{\circ} \mathrm{C}$.

Other events observed in these curves are close to the temperature range of $200-300^{\circ} \mathrm{C}$. These events can be associated with the onset of degradation and decomposition of organic compounds such as starches and fibers. The possibility of using this raw material as a dietary enrichment was evidenced by its functional and technological properties confirming its suitability for use in the food industry.

\section{Conclusion}

D Terminalia catappa has a high-yield pulp with $\mathrm{pH}$ and soluble solids values that are suitable for use in the fruit pulp and beverage industry; its acidic $\mathrm{pH}$ and the high Brix values leads to savings due to reduced sweetener usage and in their acidification process; 
$\checkmark$ The dry matter based nutritional analysis showed favorable results due to the high content carbohydrates, ash, and fibers, which were confirmed by the scanning electron microscopy of the defatted flour;

D The spongy aspect of the post-extraction material shows its high water and oil absorption capacity, evidenced its properties confirming its suitability for use in the food industry;

D This analytical knowledge increases its technological and functional potential, showing that its use in foods, when consumed in natura or when combined with other food sources in culinary preparations can add value to this fruit as a raw material or in combination with other food preparations.

\section{References}

Abdille, M. H., Singh, R. P., Jayaprakasha, G. K., \& Jena, B. S. (2005). Antioxidant activity of the extracts from Dillenia indica fruits. Food Chemistry, 9(4), 891-896. http://dx.doi.org/10.1016/j. foodchem.2004.09.002.

Ajayi, I. A., Oderinde, R. A., Taiwo, V. O., \& Agbedana, E. O. (2008). Short-term toxicological evaluation of Terminalia catappa, Pentaclethra macrophylla and Callophyllum inophyllum seed oils in rats. Food Chemistry, 106(2), 458-465. http://dx.doi.org/10.1016/j. foodchem.2007.05.093.

Arrázola, P. G., Buelvas, D. H., \& Arrieta, D. Y. (2008). Aprovechamiento de las características nutricionales del almendro de la india (terminalia catappa 1.) como suplemento en la alimentación animal. Revista de Medicina Veterinária e Zootecnia da Universidade de Córdoba, 13(1), 1205-1214.

Association of Official Analytical Chemists - AOAC. (2000). Official Methods of Analysis of International (17th ed.). Gaithersburg: AOAC.

Brasil, Agência Nacional de Vigilância Sanitária. (1998 january 16). Aprova o regulamento técnico sobre a informação nutricional complementar (Portaria $\mathrm{n}^{\circ} 27$, de 13 de janeiro de 1998). Diário Oficial da União.

Brasil, Ministério da Saúde, Agência Nacional de Vigilância Sanitária. (2001 january 10). Aprova o regulamento técnico sobre padrões microbiológicos para alimentos (Resolução RDC n ${ }^{\circ} 12$, de 2 de janeiro de 2001). Diário Oficial da União.

Brasil, Ministério da Saúde, Agência Nacional de Vigilância Sanitária. (2003 december 26). Regulamento técnico sobre rotulagem nutricional de alimentos embalados (Resolução RDC n 360, de 23 de dezembro de 2003). Diário Oficial da União.

Cavalcante, M. A., Maia, G. A., Figueiredo, R. W., \& Teixeira, V. A. M. (1986). Características físicas e químicas da castanhola, Terminalia catappa L. Ciências Agronômicas, 17(1), 111-116.

Chen, P. S., Li, J. H., Liu, T. C., \& Lin, T. C. (2000). Folk medicine of Terminalia catappa and its major tannin component, punicalagin, are effective against bleomycin-induced genotoxicity in Chinese hamster ovary cells. Cancer Letters, 152(2), 115-122. http://dx.doi. org/10.1016/S0304-3835(99)00395-X. PMid:10773401.

Chyau, C. C., Ko, P. T., \& Mau, J. L. (2006). Antioxidant properties of aqueous extracts from Terminalia catappa leaves. LebensmittelWissenschatt und-Technologia, 39(10), 1099-1108. http://dx.doi. org/10.1016/j.lwt.2005.07.016.

Chyau, C. C., Tsai, S. Y., Ko, P. T., \& Mau, J. L. (2002). Antioxidant properties of solvent extracts from Terminalia catappa leaves.
Food Chemistry, 78(4), 483-488. http://dx.doi.org/10.1016/S03088146(02)00162-0.

Costa, W. S., Suassuna, J. Jr., Mata, M. E. R. M. C., \& Queiroz, A. J. M. (2004). Influência da concentração de sólidos solúveis totais no sinal fotoacústico de polpa de manga. Revista Brasileira de Produtos Agroindustriais, 6(2), 141-147. http://dx.doi.org/10.15871/15178595/rbpa.v6n2p141-147.

Devries, J. W. (2009). Total dietary fiber: analytical progress. Minneapolis: Medalion Laboratories. Retrieved from http://www.medlabs.com/ file.aspx?FileID $=89$

Fan, Y. M., Xu, L. Z., Gao, J., Wang, Y., Tang, X. H., Zhao, X. N., \& Zhang, Z. X. (2004). Phytochemical and antiinflamatory studies on Terminalia catappa. Fitoterapia, 75(3-4), 253-260. http://dx.doi. org/10.1016/j.fitote.2003.11.007. PMid:15158981.

Fennema, O. R. (2010). Química de alimentos (4th ed). Porto Alegre: Artmed.

Fyhrquist, P., Mwasumbi, L., Haeggström, C. A., Vuorela, H., Hiltunen, R., \& Vuorela, P. (2002). Ethnobotanical and antimicrobial investigation on some species of Terminalia and Combretum (Combretaceae) growing in Tanzania. Journal of Ethnopharmacology, 79(2), 169-177. http://dx.doi.org/10.1016/S0378-8741(01)00375-0. PMid:11801378.

Gonçalves, M. F. V., Sarmento, S. B. S., Dias, C. T. S., \& Marquezini, N. (2009). Tratamento térmico do amido de batata-doce (Ipomoea batatas L.) sob baixa umidade em micro-ondas. Ciência e Tecnologia de Alimentos, 29(2), 270-276. http://dx.doi.org/10.1590/S010120612009000200005.

González-Mendoza, M., Mora, C. J., Villarroel, J., \& Mendoza, Y. M. (2009). Contenido de calcio, fósforo y magnésio de la semilla de almendrón (Terminalia catappa Linn.). Revista Odontológica de los Andes, 4(1), 31-36.

Henry, B. S. (1996). Natural food colours. In G. A. F. Hendry \& J. D. Houghton. Natural food colorants (chap. 2, pp. 40-79). Great Britain: Chapman \& Hall.

Hunterlab. (1996). CIE $L^{*} a^{*} b^{*}$ color scale (Applications Note, Vol. 8, No. 7, pp. 1-4). Virginia. Retrieved from http://www.elfiz2.kee.hu/ cie/newcie/nc/DS014-43.pdf

Instituto Adolfo Lutz - IAL. (1985). Normas analíticas do Instituto Adolfo Lutz: métodos químicos e físicos para análise de alimentos (3rd ed.). São Paulo: IAL.

Ivani, S. A., Silva, B. M. S., Oliveira, C., \& Môro, F. V. (2008). Morfologia de frutos, sementes e plântulas de castanheira (Terminalia catappa L. - Combretaceae). Revista Brasileira de Fruticultura, 30(2), 517522. http://dx.doi.org/10.1590/S0100-29452008000200043.

Khatoon, S., Singh, N., Srivastava, N., Rawat, A., \& Mehrotra, S. (2008). Chemical evaluation of seven Terminalia species and quantification of important polyphenols by TLC. Journal of Planar Chromatography, 21(3), 167-171. http://dx.doi.org/10.1556/JPC.21.2008.3.2.

Kim, D., Jeong, S. W., \& Lee, C. Y. (2003). Antioxidant capacity of phenolic phytochemicals from various cultivars of plums. Food Chemistry, 81(3), 321-326. http://dx.doi.org/10.1016/S0308-8146(02)00423-5.

Ko, T. F., Weng, Y. M., \& Chiou, Y. Y. (2002). Squalene content and antioxidant activity of Terminalia catappa Leaves and seeds. Journal of Agricultural and Food Chemistry, 50(19), 5343-5348. http://dx.doi. org/10.1021/jf0203500. PMid:12207472.

Lehninger, A. L., Nelson, D. L., \& Cox, M. M. (2002). Princípios de bioquímica (4th ed.). São Paulo: Sarvier.

Lima, R. M. T. (2012). Fruto da Castanhola (terminalia catappa linn.): compostos bioativos, atividade antioxidante e aplicação tecnológica (Master's thesis). Universidade Federal do Piauí, Teresina. 
Lin, C. C., Hsu, Y. F., \& Lin, T. C. (2001). Antioxidant and free radical scavenging effects of the tannins of Terminalia catappa. Researsh Anticancer, 21(1A), 237-243. PMid:11299741.

Liu, T. Y., Ho, L. K., Tsai, Y. C., Chiang, S. H., Chao, T. W., Li, J. H., \& Chi, C. W. (1996). Modification of mitomycin C-induced clastogenicity by Terminalia Catappa L. in vitro and in vivo. Cancer Letters, 105(1), 113-118. http://dx.doi.org/10.1016/0304-3835(96)04269-3. PMid:8689625.

Manganaro, M. M. (2008). Nutrição aplicada a enfermagem. In G. F. Murta. Saberes e práticas: guia para ensino e aprendizado de enfermagem (4th ed). São Caetano do Sul: Difusão.

Marques, M. R., Paz, D. D., Batista, L. P. R., Barbosa, C. O., Araújo, M. A. M., \& Moreira-Araújo, R. S. R. (2011). Composição física, físico química, química, análise do teor de fenólicos totais e poder antioxidante in vitro de frutos de castanhola (Terminalia catappa Linn.). Revista Ciência e Tecnologia de Alimentos, 32(1), 209-213.

Martini, N. D., Katerere, D. R. P., \& Eloff, J. N. (2004). Biological activity of five antibacterial flavonoids from Combretum erythrophyllum (Combretaceae). Journal of Ethnopharmacology, 93(2-3), 207-212. http://dx.doi.org/10.1016/j.jep.2004.02.030. PMid:15234754.

Matos, F. J. A., Alencar, J. W., Craveiro, A. A., \& Machado, M. I. L. (1992). Ácidos graxos de algumas oleaginosas tropicais em ocorrência no nordeste do Brasil. Quimica Nova, 15(3), 181-185.

Motta, J. D. (2005). Construção e avaliação do colorímetro para produtos agrícolas (Master's thesis). Universidade Federal de Campina Grande, Campina Grande.

Nagappa, A. N., Thakurdesai, P. A., Venkat Rao, N., \& Singh, J. (2003). Antidiabetic effect of Terminalia catappa Linn fruits. Ethnopharmacology, 88(1), 45-50. http://dx.doi.org/10.1016/S0378-8741(03)00208-3. PMid:12902049.

Oliveira, J. T. A., Vasconcelos, I. M., Bezerra, L. C. N. M., Silveira, S. B., Monteiro, A. C. O., \& Moreira, R. A. (2000). Composition and nutritional properties of seeds from Pachira aquatica Aubl, Sterculia striata StHil et Naud and Terminalia catappa Linn. Food Chemistry, 70(2), 185-191. http://dx.doi.org/10.1016/S0308-8146(00)00076-5.

Paula, A. A. (2008). Caracterização físico-química e avaliação do potencial antioxidante dos frutos da Terminalia catappa Linn (Master's thesis). Universidade Estadual do Sudoeste da Bahia, Itapetinga.

Pontes, L. V. (2004). Avaliação sensorial e instrumental da cor de misturas em pó para refresco, bebida isotônica e gelatina utilizando corantes naturais (Master's thesis). Universidade Federal de Viçosa, Viçosa.

Ramos, E. M., \& Gomide, L. A. M. (2007). Avaliação objetiva da cor. In E. M. Ramos \& L. A. M. Gomide (Eds.), Avaliação da qualidade de carnes: fundamentos e metodologias (chap. 7, pp. 287-370). Viçosa: UFV.

Roach, S. (2009). Promovendo a saúde fisiológica. In S. Roach, Enfermagem na saúde do idoso. Rio de Janeiro: Guanabara Koogan. Tradução de: Introductory Gerontological Nursing. Programa do livro texto, Anhanguera Educacional S. A.

Saleem, A., Husheem, M., Härkönen, P., \& Pihlaja, K. (2002). Inhibition of cancer cell growth by crude extract and the phenolics of Terminalia chebula retz. fruit. Journal of Ethnopharmacology, 81(3), 327-336. http://dx.doi.org/10.1016/S0378-8741(02)00099-5. PMid:12127233.

Santos, O. V. (2008). Desenvolvimento de barras de alto teor proteico a partir da castanha-do-Brasil (Master's thesis). Universidade Federal do Pará, Belém.
Santos, O. V., Corrêa, N. C. F., Soares, F. A. S. M., Gioielli, L. A., Costa, C. E. F., \& Lannes, S. C. S. (2012). Chemical evaluation and thermal behavior of Brazil nut oil obtained by different extraction processes. Food Research International, 47(2), 253-258. http://dx.doi. org/10.1016/j.foodres.2011.06.038.

Santos, O. V., Corrêa, N. C. F., Carvalho, R. N. Jr, Costa, C. E. F., França, L. F., \& Lannes, S. C. S. (2013). Comparative parameters of the nutritional contribution and functional claims of Brazil nut kerners, oil and defatted cake. Food Research International, 51(2), 841-847. http://dx.doi.org/10.1016/j.foodres.2013.01.054.

Silva, D. J., \& Queiroz, A. C. (2002). Análise de alimentos: métodos químicos e biológicos. Viçosa: Editora UFV.

Silva, N., Junqueira, V. C. A., \& Silveira, N. F. A. (2001). Manual de métodos de análise microbiológica de alimentos (2nd ed.). São Paulo: Varela.

Silveira, M. O. O. (1989). Preparo de amostras biológicas para microscopia de varredura eletrônica. In W. Souza (Ed.), Manual sobre técnicas básicas em microscopia eletrônica de varredura: técnicas básicas (Vol. 1, pp. 172-182). Rio de Janeiro: Sociedade Brasileira de Microscopia Eletrônica.

Sousa, M. S. B., Vieira, L. M., \& Lima, A. (2011). Fenólicos totais e capacidade antioxidante in vitro de resíduos de polpas de frutas tropicais. Brazilian Journal of Food Technology, 14(3), 202-210. http://dx.doi.org/10.4260/BJFT2011140300024.

Souto, P. C., Sales, F. C. V., Souto, J. S., Santos, R. V., \& Sousa, A. A. (2008). Biometria de frutos e número de sementes de Calotropis procera (Ait.) R. Br. no semiárido da Paraíba. Revista Verde, 3(1), 108-113.

Statsoft Inc. (1995). Statistic for Windows, Versão 7.0. USA: StatSoft.

Stoclet, J. C., Chataigneau, T., Ndiaye, M., Oak, M. H., El Bedoui, J., Chataigneau, M., \& Schini-Kerth, V. B. (2004). Vascular protection by dietary polyphenols. European Journal of Pharmacology, 500(1-3), 299313. http://dx.doi.org/10.1016/j.ejphar.2004.07.034. PMid:15464042.

Tanaka, T., Nonaka, G. I., \& Nishioka, I. (1986). Tannins and related compounds. Isolation and characterization of four new hydrolyzable tannins, terflavins A and B, tergallagin and tercatain from the leaves of Terminalia catappa. L. Chemical \& Pharmaceutical Bulletin, 34(3), 1039-1049. http://dx.doi.org/10.1248/cpb.34.1039.

Teixeira, H. L. (2010). Composição química e perfil de ácidos graxos da castanha do fruto da castanhola (Terminalia catappa Linn) (Master's thesis). Universidade Estadual do Sudoeste da Bahia, Itapetinga.

Thomson, L. A. J., \& Evans, B. (2006). Terminalia catappa. In C. R. Elevitch (Ed.), Species profiles for pacific Island agroforestry: permanent agriculture resources. Hōlualoa: Agroforestry. Retrieved from http:// www.traditionaltree.org/

Van Soest, P. J. (1967). Symposium on factors influencing teh voluntary intake of herbage by ruminants: voluntary intake in relation to chemical composition and digestibility. Journal of Animal Science, 24(3), 834-843.

Wang, J., \& Mazza, G. (2002). Effects of anthocyanins and other phenolic compounds on the production of tumor necrosis factor alpha in LPS/IFN-gamma-activated RAW 264. 7 macrophages. Journal of Agricultural and Food Chemistry, 50(15), 4183-4189. http://dx.doi. org/10.1021/jf011613d. PMid:12105943.

Yonemoto, P. G., Calori-Domingues, M. A., \& Franco, C. M. L. (2007). Efeito do tamanho dos grânulos nas características estruturais e físico-químicas do amido de trigo. Ciência e Tecnologia de Alimentos, 27(4), 761-771. http://dx.doi.org/10.1590/S0101-20612007000400015. 